\title{
Correction to: On the magnitude and dynamics of eddy covariance system residual energy (energy balance closure error) in subsurface drip-irrigated maize field during growing and non-growing (dormant) seasons
}

\author{
Sumantra Chatterjee ${ }^{1}$. Suat Irmak ${ }^{2}$. Jose O. Payero ${ }^{3}$. Ayse Kilic ${ }^{4}$ Lameck O. Odhiambo ${ }^{2}$. Daran Rudnick ${ }^{2}$. \\ Vivek Sharma ${ }^{2} \cdot$ David Billesbach $^{2}$
}

Published online: 5 August 2019

(c) Springer-Verlag GmbH Germany, part of Springer Nature 2019

\section{Correction to: Irrig Sci (2014) 32:471-483 \\ https://doi.org/10.1007/s00271-014-0443-3}

There were inadvertent errors in the authorship line and text. The authorship line should read as: Sumantra Chatterjee, Suat Irmak, Jose O. Payero, Ayse Kilic, Lameck O. Odhiambo, Daran Rudnick, Vivek Sharma, David Billesbach.

Page 472, 2nd paragraph: "water vapor particle" should be omitted.

Page 474, Equation 2 should be read as $S_{R E}=R_{n}$ $-(G+\lambda E+H+S+\varepsilon)$.
Figure $4 \mathrm{a}$ and $4 \mathrm{~b}$ should be reversed.

Figures 12 and 13 should be reversed.

Publisher's Note Springer Nature remains neutral with regard to jurisdictional claims in published maps and institutional affiliations.

The original article can be found online at https://doi.org/10.1007/ s00271-014-0443-3.

\section{Suat Irmak}

sirmak2@unl.edu

1 University of Houston, Houston, USA

2 Department of Biological Systems Engineering (BSE), University of Nebraska-Lincoln (UNL), 239 L.W. Chase Hall, Lincoln, NE 68583-0726, USA

3 Clemson University, Clemson, SC, USA

4 Department of Civil Engineering, School of Natural Resources, University of Nebraska-Lincoln (UNL), Lincoln, NE, USA 